\title{
Racism as a Human Rights Risk: Reconsidering the Corporate 'Responsibility to Respect' Rights
}

\author{
Erika GEORGEI* [C]
}

Keywords: antiracism, \#BlackLivesMatter, disclosure, diversity, racism

\section{INTRODUCTION}

Darnella Frazer, a teenage witness to a fatal police encounter, used social media to share her cell phone video footage capturing a white police officer casually kneeling on the neck of a handcuffed Black man named George Floyd for nearly nine minutes. Her video rapidly went viral, sparking civil unrest across the United States (US) and protests around the world. ${ }^{1}$ Independent experts of the Special Procedures of the United Nations Human Rights Council came together to issue a joint statement condemning 'systemic racism' and 'state sponsored racial violence' in the US. ${ }^{2}$ George Floyd was not the first unarmed Black person to die in police custody under questionable circumstances, ${ }^{3}$ but his murder motivated many to confront the reality of racism in American society. A broad section of the business community reacted to the civil unrest in the immediate aftermath of the murder of George Floyd with solidarity statements denouncing racism and pledges to promote racial equality. ${ }^{4}$ Brands rushed to embrace the previously untouchable

II Conflicts of interest: The author declares none.

* Erika George is the Samuel D. Thurman Professor of Law at the University of Utah S.J. Quinney College of Law, USA and Director at the Tanner Humanities Center, USA. The author thanks Daria Roithmayr, Jacoby Ballard and Florian Wettstein for constructive conversations.

1 Anthony Deutsch and Ingrid Melander, 'Protests Over George Floyd's Death Expose Raw Race Relations Worldwide', Reuters (2 June 2020), https://www.reuters.com/article/us-minneapolis-police-protests-global-idUSKBN2392PE (accessed 12 July 2021).

2 Independent Experts of the Special Procedures of the United Nations Human Rights Council, 'Statement on the Protests Against Systemic Racism in the United States', OHCHR (5 June 2020), https://www.ohchr.org/EN/ NewsEvents/Pages/DisplayNews.aspx?NewsID=25927 (accessed 25 February 2021).

3 Code Switch, 'A Decade of Watching Black People Die', NPR (31 May 2020), https://www.npr.org/2020/05/29/ 865261916/a-decade-of-watching-black-people-die (accessed 16 July 2021).

4 Gillian Friedman, 'Here's What Companies are Promising to Do to Fight Racism', New York Times (23 August 2020), https://www.nytimes.com/article/companies-racism-george-floyd-protests.html (accessed 5 July 2021). 
\#BlackLivesMatter movement in marketing campaigns. Business leaders expressed interested in evaluating how particular policies and practices operate in ways that serve to promote racial discrimination or perpetuate racial inequality. ${ }^{5}$

Now, a year later, protests have subsided and the officer who killed George Floyd has been tried, convicted, and sentenced for the crime. As the United Nations Working Group on Business and Human Rights launches the UNGPs +10 initiative to celebrate the tenth anniversary of the UN Guiding Principles on Business and Human Rights (UNGPs) this year to chart a course of action for implementing them more broadly, it is especially timely to reconsider what the business responsibility to respect human rights entails in the context of racialized capitalism and to reflect on how businesses could respond more effectively to calls for racial justice. There are lessons to be learned from the way businesses have engaged with \#BlackLivesMatter activists and the broader racial justice movement.

\section{From Reliance on Racism to Respect for Human Rights}

First, it is important to acknowledge the ways some commercial actors benefited from using racism to justify labour exploitation. The economic prosperity the United States of America enjoys today undeniably rests upon the foundations of the transatlantic slave trade and the labour of generations of enslaved people of African descent. The indentured labour of Chinese migrants made completion of the transcontinental railroad possible, facilitating a scale of trade and transport that allowed American industry to create a powerful economy. Despite their contributions to creating the wealth of the nation, communities of colour lived under 'Jim Crow' laws mandating racial segregation and were largely excluded from equal access to educational and economic opportunities.

The history of racism and colonialism has rendered workers of colour more vulnerable than white workers and present racial discrimination continues to reduce employment options, making it more difficult for workers of colour to avoid exploitation in labour markets. Racial exploitation persists in digital economy industries where it is predominantly people of colour who disproportionately comprise the on-demand, inexpensive and expendable workforce that drives for rideshare services firms or that does the electronic piecework necessary to train algorithms for the artificial intelligence industry. ${ }^{6}$ Migrant workers, who are racial minorities, make up the majority of the US agricultural workforce and are categorically excluded from certain labour law protections. ${ }^{7}$ When a company uses uncompensated or undercompensated prison

\footnotetext{
5 The Business and Human Rights Resource Centre has a timeline of selected business responses to the murder of George Floyd available here: Business and Human Rights Resource Centre, 'USA: Company Executives Speak Out Against Racism Following the Killings of George Floyd, Breonna Taylor \& Tony McDade by Police', https:// www.business-humanrights.org/en/latest-news/usa-company-executives-speak-out-against-racism-following-thekillings-of-george-floyd-breonna-taylor-tony-mcdade-by-police/ (accessed 5 July 2021).

6 Daria Roithmayr, Racism Pays, unpublished manuscript on file with author, 25 July 2021; Paisley Rekdal, 'West: A Translation', www.westtrain.org (accessed 31 July 2021).

7 US Department of Agriculture Economic Research Service, 'Farm Labor Size and Composition of US Agricultural Workforce', US Department of Agriculture Economic Research Service (22 April 2020), https://www.ers.usda.gov/ topics/farm-economy/farm-labor/\#demographic (accessed 27 July 2021); Juan F Perea, 'The Echoes of Slavery:
} 
labour it relies on an inmate labour force that is disproportionately Black due to racial disparities in the administration of criminal justice - it derives benefits from the 'New Jim Crow' ${ }^{8}$ The position of women of colour can be even more precarious, with racism often compounded by sexism.

It is also important to appreciate the ways some business leaders used their influence to improve race relations. For example, the Reverend Leon Sullivan, a General Motors board member and African American pastor used his influence to oppose the racist laws of the Apartheid regime in South Africa where the corporation had operations. He advocated for corporate civil disobedience and introduced the Sullivan Principles, a code of conduct eventually adopted by most major multinational corporations operating in South Africa calling for equal pay, fairness in employment, and an end to workplace racial segregation. ${ }^{9}$ When white segregationists in Atlanta refused to support an integrated dinner to recognize the Nobel Peace Prize award won by Martin Luther King Jr in 1964, Coca-Cola CEO, J. Paul Austin, intervened, threatening to take the company elsewhere, unless the white business community supported the city's integrated celebration, because as an international business the company could not remain in a city that would not honour a Nobel Prize winner. ${ }^{10}$

\section{Recognizing Racism as a Human Rights Risk}

The International Bill of Human Rights prohibits discrimination. The Universal Declaration of Human Rights provides that 'all human beings are born free and equal in dignity and rights'; both the International Covenant on Civil and Political Rights and the International Covenant on Economic, Social and Cultural Rights prohibit discrimination on the basis of race, colour, and national origin among other distinctions. The United Nations Declaration on the Elimination of All Forms of Racial Discrimination reaffirms the importance of 'eliminating racial discrimination throughout the world in all its forms and manifestations' and the International Convention on the Elimination of All Forms of Racial Discrimination (CERD) codifies the importance of taking effective measures to end polices that have the effect of creating racial divisions or perpetuating racial discrimination. ${ }^{11}$ Racial discrimination violates international human rights law.

Recognizing the Racist Origins of Agricultural and Domestic Worker Exclusion from the National Labor Relations Act' (2011) 72 Ohio State Law Journal 95.

8 Michelle Alexander, The New Jim Crow: Mass Incarceration in the Age of Colorblindness (New York: The New Press, 2012) 180; Ashley Nellis, 'The Color of Justice: Racial and Ethnic Disparity in State Prisons', The Sentencing Project (14 June 2016), https://www.sentencingproject.org/publications/color-of-justice-racial-and-ethnic-disparity-instate-prisons/ (accessed 31 July 2021).

9 Jessica Ann Levy, 'Black Power in the Boardroom: Corporate America, the Sullivan Principles, and the AntiApartheid Struggle' (2020) 21 Enterprise \& Society 170-209.

10 Jim Burress, 'The Time Coca-Cola Got White Elites in Atlanta to Honor Martin Luther King, Jr.', NPR (4 April 2015), https://www.npr.org/sections/codeswitch/2015/04/04/397391510/when-corporations-take-the-lead-on-socialchange (accessed 5 July 2021).

11 CERD defines 'racial discrimination' as 'any distinction, exclusion, restriction or preference based on race, colour, descent, or national or ethnic origin which as the purpose or effect of nullifying or impairing the recognition, enjoyment or exercise, on an equal footing, of human rights and fundamental freedoms in the political, economic, social, cultural or any 
Business enterprises have a responsibility to respect human rights. To that end, the UNGPs stipulate businesses: 'should avoid infringing on the human rights of others and should address adverse human rights impacts with which they are involved'. ${ }^{12}$ While the UNGPs must be read to incorporate by reference the broad anti-discrimination provisions contained in the International Bill of Human Rights, they are largely race neutral, in that the UNGPs do not make express reference to the CERD. The term 'race' does not appear at all in the text of the UNGPs and reference to 'national or ethnic minorities', which could be read as a proxy for race, appears only once - in a commentary explaining state obligations to promulgate policies and regulations that require business to respect human rights while recognizing specific challenges that particular groups face.

Although the UNGPs are largely silent on the subject of 'race' it is imperative to read into them an implicit recognition of racism as a human rights violation. Certain provisions of the UNGPs could inform effective strategies to reduce the human rights risk of racial discrimination. Conducting human rights due diligence and impact assessments, providing public data disclosures, and using leverage to prevent or mitigate problems could all contribute to creating the conditions necessary for eradicating racism or reducing its impact.

\section{A. Due Diligence to Detect Discrimination and Addressing the Adverse Impacts of Racism}

Business leaders have recently expressed renewed interest in doing diligence to determine the ways certain products, policies and practices operate to facilitate or perpetuate racial discrimination. Microsoft announced it would stop providing facial recognition technology to law enforcement due to racial bias, until legal protections to regulate their use are put in place. ${ }^{13}$ Amazon issued a self-imposed moratorium on the use of its facial recognition products by police. ${ }^{14}$ IBM, a company that provided the tracking technology used by Nazis to facilitate crimes against humanity during WWII, has now gone on record opposing the use of its technology for mass surveillance and racial profiling as a violation of basic human rights and fundamental freedoms inconsistent with the company's stated values of trust and transparency. ${ }^{15}$ These actions indicate that businesses are identifying and accounting for how products may cause or contribute to human rights abuses - just as the UNGPs urge.

other field of public life'. International Convention on the Elimination of All Forms of Racial Discrimination, CERD/ SP/43 (adopted on 21 December 1965, entered into force on 4 January 1969).

12 UNGP 11 in Human Rights Council, 'Guiding Principles on Business and Human Rights: Implementing the United Nations "Protect, Respect and Remedy” Framework', A/HRC/17/31 (21 March 2011).

13 Jay Greene, 'Microsoft Won't Sell Police its Facial Recognition Technology, Following Similar Moves by Amazon and IBM', Washington Post (11 June 2020), https://www.washingtonpost.com/technology/2020/06/11/microsoft-facialrecognition/ (accessed 25 February 2021).

14 Bobby Allyn, 'Amazon Halts Police Use of its Facial Recognition Technology', NPR (10 June 2020), https:// www.npr.org/2020/06/10/874418013/amazon-halts-police-use-of-its-facial-recognition-technology?t=1627908782862 (accessed 25 February 2021).

15 Hannah Denham, 'IBM's Decision to Abandon Facial Recognition Technology Fueled by Years of Debate', Washington Post (11 June 2020), https://www.washingtonpost.com/technology/2020/06/11/ibm-facial-recognition/ (accessed 24 July 2021). 


\section{B. Disclosure, Diversity and Racial Disparity}

While corporate policy commitments to embracing diversity abound, companies have been less forthcoming with making diversity disclosures to the general public. Shareholders and stakeholders are seeking information about equity, diversity and inclusion. The shareholder advocates at As You Sow have created a Racial Justice Scorecard as part of their Racial Justice Initiative to ensure that 'concrete actions' follow corporate racial justice solidarity statements and to help end corporate complicity in systemic racism. ${ }^{16}$ Along with its CEO Blueprint for Racial Equity, JUST Capital launched an initiative to advance racial equity in corporate America through tracking diversity and equity data including workforce demographics, pay equity, and anti-discrimination policies. ${ }^{17}$ To date, few of America's largest firms publicly disclose the disaggregated demographic data they are required to report to the government. Firms may be reluctant to share demographic data that would reveal a significant lack of diversity in corporate leadership or a workforce composition that largely excludes or fails to be representative of significant segments of the purchasing population. In order to track the efficacy of efforts to address adverse human rights impacts, the UNGPs recommend a review of gender-disaggregated data but remain silent with respect to race-disaggregated data. ${ }^{18}$

\section{Leveraging Leadership to Promote Change}

In responding to demands to deal with racism, a more expansive appreciation of the business community's leverage in society is warranted. The UNGPs appear to contemplate leverage in a rather limited way - as pertaining primarily to particular entities over which a company has some influence due to a contractual relationship. However, corporations can influence how different people and populations are perceived in the public imagination through advertising. PepsiCo recently retired brands rooted in racist stereotypes, which were criticized as nostalgic for chattel slavery. ${ }^{19}$ Corporations are using leverage to withhold support for policies that have a disproportionately adverse impact on racial minorities. After a group of Black executives led by former American Express CEO Ken Chenault and outgoing Merck CEO Ken Frazier called on corporate America to publicly oppose discriminatory state laws passed to make it harder for Black

\footnotetext{
16 As You Sow, 'Racial Justice \& Workplace Equity Scorecards', https://www.asyousow.org/our-work/social-justice/ racial-justice (accessed 5 July 2021).

17 JUST Capital, 'The Corporate Racial Equity Tracker', https://justcapital.com/reports/corporate-racial-equitytracker/ (accessed 5 July 2021); PolicyLink et al, ‘A CEO Blueprint for Racial Equity’, https://www.policylink.org/ resources-tools/ceo-blueprint-for-racial-equity (accessed 5 July 2021); JUST Capital, '2021 CEO Blueprint for Racial Equity', https://justcapital.com/reports/explore-the-2021-ceo-blueprint-for-racial-equity/ (accessed 5 July 2021).

18 UNGP 20. Commentary to UNGP 20 recommends the collection of gender disaggregated data to track the efficacy of efforts to address adverse human rights impacts but does not mention race. Commentary to UNGP 21 recommends that businesses 'know and show' - report on how adverse impacts are addressed. Human Rights Council, 'Guiding Principles on Business and Human Rights: Implementing the United Nations “Protect, Respect and Remedy" Framework', A/HRC/ 17/31 (21 March 2011).

19 Jeff Beer, 'PepsiCo is Retiring the Aunt Jemima Brand and it's about Damn Time', Fast Company (17 June 2020), https://www.fastcompany.com/90517967/pepsico-is-retiring-the-aunt-jemima-brand-and-its-about-damn-time (access 25 February 2021).
} 
people to vote, hundreds of companies publicly announced support for the introduction of a federal law to prevent discrimination in voting. ${ }^{20}$ Leverage can be used to lead.

Some businesses are going above and beyond the rather modest aim of merely avoiding complicity in rights violations to taking affirmative actions to advance racial justice. As demographic trends indicate people of colour will make up the majority of the population in the United States, there is a strong business case to be made against bigotry. Firms may find competitive advantage in advancing racial equity. ${ }^{21}$ Addressing racial inequality could increasingly become a business imperative.

\section{RECONSIDERING CORPORATE RESPONSIBILITY: INCORPORATING AN ANTIRACIST ApPROACH}

Corporate responses to the recent racial justice protest movements confirm research findings related to the power of public pressure to expand the social responsibility priorities of business enterprises, at least rhetorically, if only temporarily. ${ }^{22}$ The UNGPs ground the corporate responsibility to respect human rights in the basic expectation society has of business' - not in international law. While a critical mass of the public are pressing for systemic change and structural long-term solutions to racial discrimination, the problem with rooting corporate responsibility to address racism in public opinion is that it shifts and is shaped by culture, community norms and context. Indeed, support for racial justice is already waning, with levels of white support for \#BlackLivesMatter lower than they were a year ago. ${ }^{23}$ Sustaining momentum to support the movement for Black lives in the business community will require courageous moral leadership on the part of business executives, continued pressure from the public, and a reordering of market incentives such that promoting racial equity becomes profitable.

Efforts to improve the efficacy of corporate responses to human rights risks would be enriched by the adoption of antiracist approaches. Antiracism rejects the idea that 'race neutral' and 'colour-blind' policies will be adequate to advance equality. ${ }^{24}$ Antiracism challenges the racist ideas that lead to the racist actions that create and perpetuate racial inequality. When inequities are attributed to the inferiority or superiority of a given racial group, antiracism recognizes this reasoning as racist - because despite apparent racial differences, antiracism sees all races as equal. Antiracism attributes existing racial

\footnotetext{
20 Jessica Dinapoli, 'More than 150 Companies Urge US Congress to Pass Voting Rights Act', Reuters (14 July 2021), https://www.reuters.com/world/us/more-than-150-companies-urge-us-congress-pass-voting-rights-act-2021-07-14/ (accessed 14 July 2021); Shawna Chen, '72 Black Executives Call on Corporate America to Fight Voting Restrictions', Axios (31 March 2021), https://www.axios.com/black-executives-georgia-voting-restrictions-93c41926-1a64-44869c71-47448d36f227.html (accessed 16 July 2021).

21 FSG and PolicyLink, 'The Competitive Advantage of Racial Equity', https://www.fsg.org/publications/ competitive-advantage-racial-equity\#download-area (accessed 5 July 2021).

22 Erika George, Incorporating Rights: Strategies to Advance Corporate Accountability (New York: Oxford University Press, 2021).

23 Susan Page, 'Stark Divide on Race, Policing, Emerges Since George Floyd's Death USA Today/IPSOS Poll Shows', USA Today (5 March 2021), https://eu.usatoday.com/story/news/politics/2021/03/05/americans-trust-black-livesmatter-declines-usa-today-ipsos-poll/6903470002/ (accessed 16 July 2021).

24 Ibram X Kendi, How to Be An Antiracist (New York: Random House, 2019).
} 
inequities in a society to racist policies and practices, not to inherent racial differences between people.

Incorporating an antiracist approach to business and human rights analysis would entail an examination of the policies and practices that are causing or contributing to the adverse human rights impacts that serve to entrench racial inequities. Human rights impact assessments would consider whether adverse impacts are disproportionately impacting people from particular racial groups. Conducting human rights due diligence to detect the practices, policies and patterns of behaviour that reinforce racism, and replacing them with more equitable alternatives, could have a powerful positive impact.

To be sure, corporate conduct continues to fall short of commitments. The disconnect between statements of solidarity with the \#BlackLivesMatter movement and substantive actions to end institutional racism has not gone unnoticed by stakeholders. When Adidas issued a solidarity statement, Black employees shared stories of racial discrimination experienced in the workplace, highlighting a divergence between the company's internal culture and its external image. ${ }^{25}$ Companies condemn measures to restrict fair and equal opportunity to vote, yet continue to finance the campaigns of politicians who are sponsoring discriminatory voting restrictions. ${ }^{26}$ These types of inconsistencies, between stated policy commitments and business practices, could be due to a lack of consensus on the relative importance of reducing racial inequality as an important priority in the material interest of business, absent consistent public pressure for change.

\section{From Responsibility to Opportunity}

Diversity initiatives alone will not be enough. Solidarity statements are nice but are not sufficient. Rather than active antiracism efforts, many corporations appear to be engaged in 'defensive diversity' to pre-empt accusations of prejudice. While leverage can be used to lead, it can also be used to mislead. Activist efforts can be appropriated and altered in ways that dilute demands for progress. Corporate responses to the \#BlackLivesMatter movement have included: appointing chief diversity officers, hiring consultants, conducting diversity trainings, donating money to civil rights organizations, pledging to increase the number of Black employees and board members, and reassessing practices and products that disproportionately disadvantage people of colour. ${ }^{27}$ On balance, business engagement on issues of racial inequality could prove powerfully beneficial, even if self-serving.

\footnotetext{
25 Sharon Terlep, ‘Adidas Tweeted Against Racism. Its Black Workers Say that Isn't Enough', Wall Street Journal (9 June 2020), https://www.wsj.com/articles/workers-press-adidas-estee-lauder-others-to-act-on-racism-diversity11591660452 (accessed 25 February 2021).

26 Brian Slodysko, 'Georgia's Voting Bill: Criticized and Funded by Corporations', Christian Science Monitor (5 April 2021), https://www.csmonitor.com/USA/Politics/2021/0405/Georgia-s-voting-bill-criticized-and-funded-by-corporations (accessed 14 July 2021).

27 Richard Feloni and Yusef George, 'These Are the Corporate Responses to the George Floyd Protests that Stand Out', JUST Capital (30 June 2020), https://justcapital.com/news/notable-corporate-responses-to-the-george-floyd-protests/ (accessed 5 July 2021).
} 
The Movement for Black Lives has a clear 'Vision for Black Lives' policy agenda which includes, among other things, an economic justice platform calling for: living wages, progressive restructuring of tax codes, rights for workers in the 'On Demand Economy' to organize, protections for workers in agriculture and other inadequately regulated industries, and the extension of worker protections to incarcerated individuals. ${ }^{28}$ Recognizing that racism is systemic, businesses should take the substantive concerns raised by the movement seriously and treat the risk of contributing to racism as a material business issue. Putting systems in place to identify and address racial inequality in workplaces and in civic spaces would be a higher priority were racism recognized as a serious human rights risk. Corporations should set metrics to measure progress and share data on racial equity in the workplace. The business community could use its political and economic leverage to defend civic freedoms and public participation in democratic governance. ${ }^{29}$

More shareholders, stakeholders and social movements are calling for more than marketing and are seeking substantive change. Courageous corporate leadership has been and will continue to be a significant factor in promoting protection for human rights. Racism is a business and human rights issue. Antiracism should be on the business and human rights agenda. The UNGPs, while race neutral, can be used to advance racial justice. To have a meaningful and measurable impact on addressing inequality and implementing the UNGPs more broadly, the business and human rights movement must not avoid confronting racism. ${ }^{30}$

\footnotetext{
28 Movement for Black Lives, 'Economic Justice', https://m4bl.org/policy-platforms/economic-justice/ (accessed 24 July 2021).

29 Bennett Freeman et al, Shared Space Under Pressure: Business Support for Civic Freedoms and Human Rights Defenders: Guidance for Companies (London, Geneva and New York: Business and Human Rights Resource Centre and International Service for Human Rights, 2018).

30 Erika George, Jena Martin and Tara Van Ho, 'Reckoning: A Dialogue about Racism, Antiracists, and Business \& Human Rights' (2021) 30 Washington International Law Journal 171-254.
} 